\title{
Politics, Policy and Poverty in Nepal
}

\author{
Bala Raju Nikku*, Azlinda Azman \\ Social Work Programme, School of Social Sciences, Universiti Sains Malaysia, 11800 Penang, Malaysia \\ *Corresponding Author: brnikku@usm.my
}

\begin{abstract}
Poverty in Nepal is deep, diverse and multifaceted. This article examines the conceptual and policy links between poverty, policies and human rights. This paper aims to provide some pathways for an increased understanding of policy and politics dimensions of poverty in Nepal. This examination is further informed by a critical social work perspective, sharpened through the authors' presentation at a USM and CSU sponsored research colloquium on poverty as a human rights violation. Beginning with a description of the present level of poverty in Nepal and the values underpinning Nepalese social policy, we then analyse anti-poverty initiatives by the Nepalese successive governments and non state actors and examine the role of Nepalese nascent social work profession in the gigantic task of crafting poverty free Nepal.
\end{abstract}

Keywords Nepal, Poverty, Social Work, Social Policy, Development Planning, Politics, Donor Agencies, Poverty studies

\section{Introduction}

"Wherever we lift one soul from a life of poverty, we are defending human rights. And whenever we fail in this mission, we are failing human rights." - Kofi Annan, former United Nations Secretary-General (2010)

'Poverty is like punishment for a crime you didn't commit. And one never really forgets either--everything serves as a constant reminder of it' (Eli Khamarov in Lives of the Cognoscenti). Poverty is an unacceptable human condition which does not have to be inevitable. But the fact is that more than one billion people live in poverty around the world and the great majority of them are women.

The last century witnessed major improvements in the health and education status of many, reflected in declining infant mortality rates, increasing life expectancy, and higher literacy rates. However, 1.2 billion people are estimated to still live on less than $\$ 1$ per day, and almost 3 billion on less than $\$ 2$ per day. About 110 million primary school age children are out of school, 60 percent of them girls. About 31 million people are infected with HIV and AIDS, and many more live without adequate food, shelter, safe water and sanitation (Global Poverty Report, 2000). The fact is that poverty remains in certain pockets of the world especially in countries like Nepal that are going/ went through wars and internal conflicts.

Despite some progress in poverty reduction in recent years, Nepal remains one of the poorest countries in the world, with a Human Development Index of 0.463 , placing it 157 th out of 187 countries listed in the Human Development Report 2013 of the United Nations Development Programme. 'Regional disparities in the incidence of poverty and illiteracy are quite stark in Nepal. In essence, regional disparity is a major dimension of poverty' (Chhetry, 2008: 204).

Successive development plans in Nepal have focused on poverty alleviation for decades, and poverty alleviation remains a declared goal of consecutive governments in Nepal. However, Nepalese today are no less poor than they were a decade ago. What were the reasons for this persistent poverty? Is it due to the internal conflicts and human rights violations in the past decades? If yes, what has been the link between human rights and poverty in a transition country like the Nepal? In recent years, the traditional view of poverty has changed as it has come to be recognized as a denial of human rights that undermines the dignity and worth of the individuals.

This paper is divided in to six sections. After a brief introduction, section two presents Nepal's geographical, political, social and economic features in brief as a back ground to the other sections. We then discuss the definitions and dimensions of poverty studies. Though a detailed discussion on academic debates about how poverty should be measured is beyond the scope of this paper. We briefly discuss methods adapted by different agencies to poverty measurements and discuss how they influence poverty alleviation policies in a donor driven country like Nepal. Section four is about poverty in development plans of Nepal. We then analyse various policy experiments with poverty eradication in section five. Finally, we conclude policy and politics dimensions of poverty in Nepal and provide a three pronged approach as a way forward in the concluding section. 


\section{Nepal: A Country in Transition}

Nepal in South Asian region is going through a series of economic and political transitions. With an average per capita Gross Domestic Product (GDP) of around US\$260, Nepal is one of the poorest countries in the region and ranks as the twelfth poorest country in the world.

The social, political and cultural changes are having their toll on the Nepalese population pushing to poorer conditions. With its ancient culture and the Himalayas as a backdrop, landlocked Nepal with 29 million people carries a romantic image. But the Country is going through a series of transitions in the last 200 years and more so in the last 60 years.

Nepal has about 60 recorded caste and ethnic groups (mostly Indo-Aryan and Mongol) and 70 languages and dialects (mostly Indo-Aryan and Tibeto-Burman). There are many indigenous ethnic (Janajati) and caste groups who have been historically disadvantaged, and who continue to lag behind in their income and asset levels, educational achievements and human development indicators, and to the extent that they are least represented in the power structure.

The late King Mahendra suspended the Parliament in 1959 and took sole charge of the country's governance in 1962. After popular protests in 1991, democratic politics was introduced but was marked by frequent changes of government. To end the autocracy, the Maoists waged a decade long insurgency beginning 1996. The last king of Nepal Gyanendra, twice assumed executive powers in 2002 and 2005. The Nepalese Parliament agreed to the peace deal in December 2007, and the Maoists emerged as the largest parliamentary party after elections in April 2008. The Monarchy was abolished a month later, and a Maoist-dominated government took office in August 2008 and declared Nepal as a federal republic. However, in less than a year political changes occurred and Maoists were in the opposition. After the death of the constituent assembly in May 2012, currently the country is governed under care taker government.

Nepal has been a recipient of foreign assistance since 1952 when it joined the Colombo Plan for cooperative, economic and social development in Asia and the Pacific. According to World Bank figures, official development assistance increased from US\$8.2 million in 1960 to US\$369 million in 2003 and then fell to US\$177 million in 2004. According to Nepal's Ministry of Finance, total foreign aid committed in fiscal year (FY) 2003 was US $\$ 555$ million, with 63.3 percent in grants and 36.7 percent in loans. In spite of these efforts the HDI that measures the average progress of a country in human development marked at 0.553 , which gives the country a rank of 144th out of 182 countries.

War has been described as 'development in reverse'. Civil wars (with an estimated average cost of $\$ 64 \mathrm{bn}$ each) and coups incur large economic costs to a country. Additionally, in the time period immediately following a major conflict, relapse is highly likely. Collier argues that the longer a country stays in a state of conflict, the more the players become established that profit from the state of commotion, making the situation increasingly intractable (Collier 2007). Many donors have been reported as losing confidence in Nepal especially during the insurgency (1996-2006) period due to excessive political interference, corruption in poverty relief efforts as well as the country's apparently poor capacity to utilize aid.

Nepal's position 'as a yam between two boulders' i.e. India and China can give Nepal not as a 'land locked' but 'land linked' position which Nepal is yet to turn to its advantage. At last, Nepal took the route of establishing multi party democracy through removal of Monarchical regime. By doing so it aims to establish substantive democracy, by seeking to address inequities in political, economic and social structures.

It is beyond the extent of this paper to discuss in depth the political, economic and social changes that took place in Nepal in the last 60 years. However, it was clear that until Nepal became a republic in May 2008, it had been ruled by monarchs or Rana regimes for most of its modern history causing its relative isolation. The rulers of Nepal are obliged to walk a tightrope not only within Nepal but also in international affairs, which have come increasingly to affect not only internal politics but the economy through politics of foreign aid (Blaikie et al 1980). It is in this context this paper explores the reasons for continued poverty and human rights situation in Nepal. According to Basnet in the editorial of The Rising Nepal Daily (2012):

"Poverty is lack of power and to live in uncertainty and insecurity. It means deprivation of the resources, capabilities, choices, security and power that are needed to provide a standard of living that brings with it the enjoyment of civil, cultural, economic, political and social rights. It violates personal freedom: its elimination should be seen as a basic entitlement and human right and not merely as a problem to be tackled by charity. Poverty so violates human rights that it must be tackled by a world that claims to be working towards full-scale adoption of human rights. Based on the fundamental principle of the equality of all human beings, it demands that nationally and internationally there is a legal duty to create a moral, political, and economic order that will grant all persons the opportunity to live with dignity".

\section{Poverty Studies and Measurements: $\boldsymbol{A}$ Brief Conceptual Outline}

Historically, poverty research has been dominated by the notion of economic well-being, and with it studies of income and consumption. Income and consumption have been used widely as proxy measures for poverty assessments. Conceptualising poverty as a one dimensional shortfall, in terms of income, consumption or expenditure has limitation as there are other non-monetary indicators do influence the 
poverty condition of a person.

Absolute poverty as 'a condition characterized by severe deprivation of basic human needs, including food, safe drinking water, sanitation facilities, health, shelter, education and information. Some scholars' identified poverty in terms of whether households or individuals have enough resources or abilities today to meet their needs?

The UNDP (1998:16) has provided six different types of poverty such as human poverty, income poverty, extreme poverty, overall poverty, relative poverty, and absolute poverty. World Bank defines poverty in absolute terms. The bank defines extreme poverty as living on less than US\$1.25 per day. Conceptualising poverty as a one dimensional shortfall, in terms of income, consumption or expenditure raises many has methodological issues.

Sens's capability notion postulates that poverty results from a lack of capability to 'function' or to 'achieve' well-being, where well-being is defined as the "ends" and capability as the "means" to achieve it (Sen,1999). The recent developments emphasize capability and social exclusion or social inclusion, to be more positive as alternative and more promising approaches to poverty analysis. One needs to disaggregate poverty in to multiple dimensions in order to understand and design policies that can alleviate poverty.

The World Bank Group (WB) now promoting shared prosperity, or inclusive economic growth. The new indicator marks a departure from how economists have traditionally measured a country's progress.

\section{Politics of Poverty Estimates}

Poverty goes beyond lack of income. It encompasses economic, social, political, cultural and governance dimensions. UNDP (1998:16) has provided six different types of poverty such as human poverty, income poverty, extreme poverty, overall poverty, relative poverty, and absolute poverty. On the other hand, UNFPA in 1996 defined urban poverty based on income, basic needs, and participant's perspective.

Uni-dimensional approach to poverty measurement refers only one variable i.e. income whereas multidimensional approach uses several indicators in order to obtain a more exhaustive and useful measure. By means of the multi-dimensional analysis it is possible to identify the main causes of poverty and therefore to adopt socio-economic policies to reduce poverty diffusions.

The trend in estimating poverty analysis is focused on defining various types of poverty and on estimating its incidence based on crude data (ADB, 2003). Wagle (2005) argues that the contemporary income and expenditure approach to poverty, which are uni-dimensional in nature, are unable to capture multi-dimensions of poverty. An influential paper by Bourguignon and Chakravarty(2003) specifies a poverty line for each dimension of poverty and to consider that a person is poor if he/ she fall below at least one of these various lines. This paper explores how to combine the various poverty lines and associated one-dimensional gaps into multi-dimensional poverty measures (Bourguignon and Chakravarty, 2003).

Poverty in Nepal, like in other countries, has largely been interpreted based on macro-economic indicators. We need to go beyond these estimations. Poverty in the midst of plenty is one of the central challenges in today's global economy and society. This rule applies to Nepal also. Some critiqued that Nepal is a rich country with poor people. While saying this they refer to rich natural resources of Nepal which are yet to be tapped and managed for the betterment of Nepalese people. The issue is - not lack of resources- but it is lack of ability to manage these resources leading to poverty. The lack of governance capacity resulting in to persistence poverty should be understood as a form of human rights violation in Nepal. Professional social work can play a vital role by working with poor and making their voices heard by policy makers.

\section{The Human Development Index (HDI): Going Beyond Income}

The Human Poverty Index is an indication of the standard of living in a country, developed by the United Nations (UN). For highly developed countries, the UN considers that it can better reflect the extent of deprivation compared to the Human Development Index. The HDI measures the average progress of a country in human development. The HDI for Nepal is 0.553 , which gives the country a rank of $144^{\text {th }}$ out of 182 countries.

\section{Micro Impact of the Macro and Adjustment Policies (MIMAP)}

The number of women and children living in poverty has increased disproportionately to the number of men, especially in the past decade in Nepal. In addition to economic factors, the rigidity of socially ascribed gender roles and women's limited access to power, education, training; productive resources are responsible for women's poverty. This situation suggests in a country like Nepal policies that are focused on special populations are also crucial in addition to macro policies.

The MIMAP as a pilot research project was initiated in Nepal during mid 1996 with the support from International Development Research Centre (IDRC) Canada. The main objective of this initiative is to analyse the micro impacts of the macro policies especially on poverty situation at local and national levels. The project aimed to increase the capability within the country to assess the impacts of globalization and liberalization policies on income distribution, expenditure pattern, living standards and other social dimensions of poverty.

In this paper, we used a multi-dimensional/multi-sectoral approach to gain an in-depth understanding poverty in Nepal. 
On the basis of findings, we argue that poverty in Nepal is a direct consequence of weak governance mechanisms, internal conflicts leading to human rights violations, failure of poverty eradication policies and human rights violations. This political instability, along with weak governance structures, corruption and low levels of civil society activism resulted in to prolonged political instability and problems with law and order. Promoting pro-poor growth, securing social development, and ensuring good governance are the three approaches combined can address the depth and diversity of poverty and policy issues in Nepal.

\section{Poverty in Development Plans of Nepal}

In this section, we present a brief analysis of 60 years of Poverty Alleviation policies (1950-2011) in Nepal. Poverty in Nepal has persisted for decades, and it is recognized as a deep-seated and complex phenomenon, for which there are no quick and easy solutions. The lives of poor people are most affected by policy actions at both micro and macro levels. Because of the multi-dimensional character of poverty, public policy actions are needed in several areas of governance. Nepal has been trying its best to formulate and implement policies that help the poor to survive and come out of the poverty trap. However, we argue that the lack of policy analysis skills, international macro financial policies, donor and aid politics, aid ineffectiveness, internal instability leaving a vast majority of Nepalese in a poverty condition.

Nepal became open for outside world in the year 1951 and the next five years were spent in a political transition to democracy, during which economic agendas hardly surfaced. The systematic drive for national economic development began in 1956, when the National Planning Commission (NPC) and the Nepal Rashtra Bank (Nepal Reserve Bank) were established.

The National Planning Commission drafted and introduced the First Five Year Plan (1956-1961) under a very unfavorable situation characterized by mass illiteracy (around 95 per cent), high mortality and fertility rates, high incidence of endemic diseases, almost no physical infrastructure in addition lack of skilled manpower and severe financial constraints

Poverty alleviation has always been an overriding concern of Nepal's development planning exercises, but only since the Sixth Plan (1981-1985) has it been explicitly stated as a development objective.

During the Seventh Plan period (1986-1990), the Government formulated its Program for the fulfillment of basic needs, the first separate plan for reducing poverty. Poverty alleviation was one of the major objectives of the Eighth Plan (1993-1997), the first national plan formulated after restoration of multi-party democracy in 1991.

The Ninth Plan (1998-2002) adopted poverty alleviation as its sole objective, and unlike previous plans, established long-term goals for improving development indicators in all sectors, based on the potential of each for reducing poverty.
While the Government has also endorsed and implemented master plans and perspective plans for reducing poverty that relate to individual sectors and subsectors, thus far these sectoral-level plans have not been integrated well with the national plan (ADB, 2002).

The Tenth five year plan of Nepal (2002-2007) adopted poverty reduction as its core focus to further address the growing poverty in the country. It aimed to achieve 4.3 percent growth rate considering the internal conflict that existed during 1996-2006 in the country. The Plan has formulated a poverty reduction strategy based on four pillars -broad based high and sustainable growth, social sector development with emphasis on human development, targeted programs with emphasis on social inclusion and improved governance. The $10^{\text {th }}$ plan's sole objective is to achieve a remarkable and sustainable reduction in the poverty level in Nepal from $38 \%$ of the population at the beginning of the Plan period to $30 \%$ by the end of the Tenth Plan, and to further reduce the poverty ratio to $10 \%$ in about fifteen years' time. The Tenth Plan categorized poverty into three dimensions, income poverty, human poverty and social exclusion. Analyzing all these dimensions in the previous years, the overall poverty and human development indices of Nepal have considerably improved.

The three year interim plan (July 2007/8- 2009/2010, त्रिवषिर्य अन्तरिम योजना) came in to force, prevailing a special moment in the country's history, will give continuity to previous achievements, and address issues specific to the transitional period in a post-conflict situation. This Plan puts special emphasis on increasing public expenditure to assist relief and generate employment as well as on peace building, reconstruction, rehabilitation, reintegration, inclusion, and revitalization of the economy. Similarly, the Plan gives special attention to women, dalits, indigenous groups, Madhesi community, the poor, inhabitants of Karnali area and people of remote areas who had been excluded from the country's economic, social and regional development process.

Fifty five years of planned development have been completed in Nepal. Although ten periodic plans have been implemented during this period, many aspects of economic and social sectors have still remained backward from the perspective of development. Due to reasons like limited availability of resources, thirty years of restrictive political environment and a decade long conflict, the development process has not been able to move ahead at the expected speed.

This fiscal year is the final year of the implementation of the current Three Years Plan (2010/11- 2013/14). It is necessary to prepare final document of the next periodic plan by the mid of July 2013 to produce the 13th periodic plan $(2013 / 14$ - 2015/16).

\section{Poverty Alleviation and Policy Achievements of Phase 1 (1970-90)}

In 1971 Nepal was identified by the United Nations as 
one of the least developed and poorest states in the world and one whose overall economic and social condition gave great cause for concern. For example in agriculture $94 \%$ of the labor force was involved but the annual rate of growth in food production per capita between 1961 and 1969 was zero. It was clear by the mid 1970's that the capacity of the predominantly agrarian economy to feed the population was not increasing. With an average per capita GDP of around $\$ 80$, a growth rate of 2.8 per cent per annum in GDP, and a population growth rate of around 2.5 percent the prospects for the future were not good; indeed as one major report stated bleakly 'Nepal is poor and is daily becoming poorer' (ARTEP 1974:1 cf Seddon 1987).

\section{Policy Achievements of Phase 2 (1990-2010)}

During this phase the country made some progresses. In 1990 the country received democracy due to popular protests. The agricultural sector contributed about 40 per cent to the total GDP and the source of livelihood to about 80 per cent of the Nepalese population. Trade, tourism and service sectors contributed to a larger proportion of GDP, while the manufacturing sector contributed only 10 per cent to the GDP. The per capita Gross National Income (GNI) is reported at US \$ 250 (The World Bank, 2003: 235).

Every two in five persons in Nepal still lives below absolute poverty line and every other person in the rural area is poor. Very high unemployment and underemployment rates of 17.4 and 32.3 per cent, respectively (NPC, 2003: 58-99) have compelled people to remain either under the vicious circle of poverty or migrate to other places within and outside the country for better opportunities of livelihood.

Out of the five development regions, the proportion of population living under extreme poverty is the highest i.e 29.2 percent in the Mid-Western Development Region, according to Human Development Report (HDR) 2013. According to the HDR 2013 the second largest population living in extreme poverty is from the Far Western Region, followed by the Central, Eastern and Western regions. The Nepal Living Standard Survey (NLSS III, made public in FY 2011/12 shows 25.2 percent population below the poverty line. So these regional variations of poverty also need to look in to in the case of Nepal.

Interim Constitution of Nepal, 2006 has embraced the principle of Inclusive development. The on-going three-year plan (2010/11- 2012/13) has targeted to alleviate poverty through the employment centered inclusive and equitable economic growth. Inclusive oriented programs are being implemented by targeting various groups and communities who are excluded from mainstream of development in the current plan. These programs have benefited women, Dalits, ethnic groups, Janajatis, Madheshi, minorities, people with different abilities and backward class, small farmers and ultra-poor families in addition to the rural communities.

\section{Experiments with Poverty Eradication}

Some of the major initiatives of the Government to reduce poverty are the Agriculture Perspective Plan (APP), economic reform, the Local Self-Governance Act (LSGA) and adoption of an interim poverty reduction strategy paper.

The APP was formulated in 1995 with a 20 -year time horizon and provides a strong basis for planning and implementing agricultural development programs in Nepal. The objective of APP is to raise the annual growth rate from around 3 percent to around 5 percent by 2015 .

Realizing the importance of decentralized mechanisms, the Government of Nepal in 1999 promulgated the LSGA. The act created 75 District Development Committees (DDCs), 58 municipalities, and 3,912 Village Development Committees (VDCs).

\section{Anti-Poverty Programme(s)}

Half of the population is under poverty line, and over the years instead of decreasing the number of families sliding in to poverty is increasing. It was 4.9 million populations in 1997 reported below poverty line reached to 9.5 millions in few years (Sharma \& Gautam 2004). The country declared democracy in 1990 with a constitutional monarchy and in 2008 declared as a republic of Nepal.

To reduce poverty by accelerating economic growth and expanding employment opportunities, the government in the early nineties initiated an extensive economic reform agenda. Reforms were introduced, for example, to liberalize trade, investment and foreign exchange regimes, unify the exchange rate, rationalize the tariff structure and the tax system, promote exports, strengthen financial and capital markets, foster private sector development, and strengthen public expenditure management (IMF, 2003). According to the 1996 Nepal Living Standards Survey, urban poverty was estimated at $23 \%$, and in the urban Kathmandu Valley at only $4 \%$, compared to overall national poverty incidence of $42 \%$ of the population. However, these early reforms did not touch the important agricultural sector in a significant way; and consequently had little impact on rural poverty.

\section{Poverty Alleviation Fund (PAF)}

Since the early 1990s, various targeted and sectoral poverty alleviation programs have been implemented by the Government. However, the majority of these programs, which were centrally planned and implemented, ignored community preferences. This, together with weak program coordination and lack of monitoring and evaluation mechanisms, caused the impact of these programs to fall well short of that envisioned. To correct these problems, the Government has established a Poverty Alleviation Fund (PAF) for the purpose of initiating and implementing various sectoral as well as targeted poverty reduction programs that are being implemented via a coordinated and 
integrated approach. The PAF will especially focuses on safety nets for the vast majority of the poor in the country.

\section{Poverty and Migration Programmes}

High unemployment rate at 17.4 per cent and high underemployment rate at 32.4 per cent compel Nepalese people to migrate within and outside the country in search of better employment opportunities. Literature reviews suggest a growing need for examining the interrelationship between many facets of migration and many levels of poverty. It is assumed that the poverty reduction strategy of Nepal is likely to succeed if it takes into account various components of migration dynamics. There is a high incidence of poverty in the regions experiencing net negative migration and that regions of in-migration are relatively better off in development indicators. Adams JR. and Page 2005 showed that on an average, a $10 \%$ increase in the share of international migrants in a country's population will lead to a $2.1 \%$ decline in the share of people living on less than $\$ 1.00$ per person per day (Adams and Page 2005).

There are also various types of migrations in Nepal such as internal and international. Internal migration constitutes in-and-out-migration between rural-to-rural, rural-to-urban, urban-to rural, and urban-to-urban areas. There are many reasons for migration of which sometimes migrants themselves do not seem to know why they have migrated to the destination or are intending to migrate.

Additionally, there are various types of time bound migrations such as seasonal migration followed by temporary, semi-permanent and possibly a permanent move, unless a migrant keeps on circulating or moving by just changing the location several times a year or more. The short or long distance migration from rural-to-rural and rural-to-urban inside the country is vital for migration analysis. Whatever the types of migration in terms of both time and space, except forced migration due to natural calamity and war, migrants usually respond to pull and push factors depending upon whether it was an individual migration or a migration involving the entire family members and other relatives.

A large majority of migrants expressed that they had migrated from the origin for better employment opportunity, for earning more income, to raise their standard of living, for education, for survival, for business or service or even environmental factors among many others. The same thing holds true for emigration and immigration. These reasons would be different by age and sex selectivity, levels of education, skills and the requirements of the receiving countries (BalKumar, 2003).

\section{Women in Poverty}

Nepal is already a state party to 24 international human rights instruments as of 2012. Equal importance should be given to the Comprehensive Peace Agreement (CPA), the Interim Constitution of Nepal 2007 and other agreements and understandings because a number of Human rights issues are embedded also with the 10-year long armed insurgency and the six-year long peace process.

Among the population /families below poverty line the brunt of poverty falls disproportionately on women and girls resulting in human deprivation in terms of access to food and nutrition, access to education, access to other development opportunities and excessive work burden. Furthermore even if a household does not fall below the poverty line but is in the poverty threshold, the share of women and girls in intrahousehold resource distribution is very low resulting in human deprivation poverty situation.

As compared to the male-headed household large proportion of female-headed households fall below the poverty line due to the gender discrimination in access to and control over productive resources and other economical and political opportunities. There is a huge income gap between men and women both in terms of opportunities for employment/income generation and in the proportion of earned income; resulting in women to remain in poverty status. Female comprise 31 percent of all paid workers as against 69 percent male (CBS, 2001). The ratio of estimated female to male earned income is 0.51 and the estimated earned income (PPP) is US\$ 949 for female as against 1868 for male (UNDP, 2004) Women remain poor due to the lack of access to and control over productive resources. During census 2001, only 17 percent of the households reported that female in their families have ownership on the house, land and the livestock.

Poverty also instigates male emigration resulting in the burden of agriculture and household maintenance upon women and with a very high chance of family disruption due to the absence of male from the family for a long duration. The proportion of the male migrants was much larger 89 percent than the proportion of female migrants 11 percent (Census, 2001). In spite of 'poverty having a woman's face' the national accounting fails to disaggregate poverty by gender both in qualitative and quantitative terms. In the absence of measuring poverty assuming individual as a unit of analysis as against household as a unit of analysis, it becomes difficult to pin-point the exact extent of self-reported feminization of poverty. This results in targeting poverty reduction. So the exact situation of women poverty should be known so that the appropriate poverty reduction strategies will come out and for that the accuracy and the extent of poverty situation should be known. The measurement of poverty done with the help of multi dimensional poverty model will be very much useful for getting the exact figure of poverty.

\section{Forestry Sector Programmes and Poverty Alleviation}

Development forest based livelihoods has given a priority. The forestry sector policy in Nepal can be divided into three broad groups, viz. privatization (pre- 1950), nationalization (1957 and up to the mid 1970s) and the community orientation which began in the late 1970s with the introduction of concept of community forestry. Forest 
Development is used as a livelihood tool for people without cultivable or agriculture lands in Nepal. It is also important for promoting livestock, making compost fertilizer, conserving environment and for watershed management by conserving ground water resources. Community and Leasehold Forestry programs have been very successful in the country in creating income-generating opportunities for the poor. In this context, the 'user-group approach' is particularly useful in mainstreaming poor and deprived communities in forestry sector activities. Given its high success, the leasehold programs would be further expanded. To deal with forest degradation, two main approaches for example the Community Forestry and Leasehold Forestry Programme have been tested in Nepal in the last 25 years.

\section{Community Forestry and Poverty Eradication}

A flagship programme for several international organisations consists of preventative measures to protect well-stocked forest areas against over-exploitation. 2. Leasehold Forestry Program a less publicized but pro poor initiative. Leasehold Forestry is a program intended to ameliorate the ecological conditions of the degraded forests in the mid-hills and to improve the livelihoods of forest-dependent poor through their active involvement in the program. Forty-year leases are provided to groups of households giving them user rights over plots of degraded forest land. They rehabilitate the land by banning grazing and by stall-feeding their livestock, and use and sell forest products such as timber, fuel wood and fodder.

\section{Leasehold Forestry}

It is a successful in enhancing various livelihood capitals of the poor families through increased fodder and livestock production and saved time in collecting forest products like grass and fire wood. Transfer of land with degraded forests to the very poor on renewable 40-year leases has the immense potential to address family poverty leading to reforestation. The program granted secured land tenure (40 years of lease) to poor families which in turn used by the poor to challenge the local power structures. But until and unless the LFUG are further strengthened, conflict over the resource may nullify the formal security of tenure.

Dhakal et al (2006) have shown how forestry programs could not address poverty of poorer households compared relatively better of households in the same community. Community forestry policies have achieved their goals in terms of the number of forest user groups formed and in improving forest cover in Nepal. Over 14,000 forestry users groups were formed in the first 12 years of the community forestry program (CFUG Database 2005). Deforestation has been halted and high forest stocks are being restored (Gautam et al., 2002) in some cases to the extent that forests are over-stocked (Nurse et. al. 2004). Wildlife populations have increased and the government is being urged to introduce wildlife control policies (Community Forestry
Division 2004). Some communities have also been able to generate funds from sales of forest products from community forests (Dongol et. al. 2002).Despite these successes, a number of studies have shown that there are negative distributional outcomes under community forestry policies, with poor households receiving less benefit from community forests than wealthier households (Dhakal et al., 2005; Agrawal, 2001; Adhikari et al., 2004).

\section{Irrigation sector Development Programmes}

The programmes aimed to promote year round irrigation in the arable land area of the country and to ensure the sustainable management of developed irrigation systems. The major policies and activities to achieve these goals include: (i) expanding small surface irrigation in the hills and surface and ground water facilities in the Terai; and (ii) repair/rehabilitate and maintain the existing farmer managed and public irrigation systems. Irrigation laws will be revised to grant WUAs the legal powers to collect irrigation charges. In the case of large and medium scale public irrigation systems, their management will be increasingly transferred to the private sector. Increased involvement of NGOs and the private sector in new irrigation development will also be encouraged.

Ajaya Dixit, editor of Water Nepal Journal argues that despite the rhetoric of electricity export, Nepal remains a net importer of energy: of both fuel and electricity. In 2007, Nepal received more electricity from India than we sold across the border. Many activists claims that Nepal should not export electricity and think of hydro dollars for its development bur generate electricity for its own consumption (Nikku, 2009; Thanju, 2008)). The reliable and cheap energy is the foundation for a prosperous Nepal. Other Hydrocrats like Ratana Sansar Shrestha argued that even if the Arun III projects was a reality, the load shedding of Nepal would have not any different, because of the World Bank conditions. Shrestha points out that these big hydropower projects will not create forward and backward linkages in the Nepalese economy.

Regmi (2004) in her doctoral study stated that "Hydel technology in Nepal is shaped by macro and micro power policy models. While the state-controlled grid system supplies energy nationally, micro-hydel projects have been romanticized and perceived as community orientated alternative system of rural electrification. The system has been designed with the premise that this is the appropriate form of power supply, often overlooking the existing power bases and the adaptive features of these hydraulic, transformative and evolutionary ensembles."

\section{Rural Electrification Programmes}

Rural Electrification was given importance as it can play important role in accelerating both agricultural and rural development. It could have a catalytic effect on agricultural 
growth by accelerating shallow tube well irrigation. In addition to supporting for the development of agro business, the extension of rural electrification would also help modernize cottage industries and improve the living standards of rural households. Accordingly, key programs are aimed at expanding grid-based rural electrification, promoting small projects where grid-based expansion is not possible, and enhancing the capacity of cooperatives for management at local levels.

\section{Human Development (Education, Health, Drinking Water and Sanitation) Programmes}

While human development has many dimensions, education, health, rural drinking water and sanitation are particularly important. In addition, basic infrastructure such as access to (even low-quality) roads, electricity and telephone communications (particularly in remote areas) can help improve living conditions for the poor in rural areas. The role of the government continue to be particularly important in the social sectors because there are many programs where costs of providing services cannot be fully captured by private providers, even though the social returns from such programmes and activities may be high, (for example, preventive programmes). (ii) But, the government is committed to increasingly decentralizing to local governments the responsibilities for primary education and health care, and involving local communities in the management of primary schools and health centers. (iii) Greater involvement of the private sector, INGOs, NGOs and CBOs is being actively promoted.

\section{Way Forward: Three Pronged Approach}

People living in poverty have the least access to power to shape the policies of poverty alleviation and are frequently denied effective remedies for violations of their rights. The evidence from Nepal described above confirms the same. We further present that Nepal's achievements in addressing poverty are notable given the country's politically difficult and conflict-ridden environment in the last two decades. We suggest that promoting pro-poor growth, securing social development, and ensuring good governance are the three approaches combined can address the depth and diversity of poverty in Nepal. Nepalese social workers can assist in the implementation of these approaches which are interrelated and implemented with political will simultaneously to alleviate poverty in Nepal.

\section{Pro-poor Growth}

A pro-poor growth model stimulates employment and other economic opportunities, and generates revenues, which can be directed, through good governance, at providing services needed by the poor and vulnerable groups. The policies that address poverty should be based on these approaches to address the poverty on the ground. Professional social work services could be used to facilitate the process of people's participation right from the policy formulation stage to implementation. This increases the policy ownership and yield better policy results on the ground.

\section{Ensuring Good Governance}

The assumption is that the poor already possess the most critical quality for poverty reduction i.e. a powerful desire to acquire and use assets to improve their own well-being and reduce their vulnerability. But there should be an environment in which poor can also play equally with their rich counterparts. To achieve this environment the good governance is the key. A strong state and a motivated bureaucracy in Nepal may be a solution to the problems of the poor.

\section{Social Development through Social Inclusion and Empowering the Poor}

Empowering poor is recognized as an essential element in creating a sense of dignity, confidence, and self-reliance in the poor and is thus important both as means and end in poverty reduction. And hence policies should aim to make poor households as actors in the policy rather making them mere policy beneficiaries. As of now the design and delivery arrangements of some targeted poverty reduction projects and policies are serving to increase the sense of dependency and powerlessness of the poor and often also their sense of political indebtedness.

\section{REFERENCES}

Adams, H. R Jr. \& Page, J. (2005). Do International Migration and Remittances Reduce Poverty in Developing Countries? World Development, 33 (10): 1645-1669

Adhikari, I. (2009). West Seti Hydel: Marred by controversy and conflict of interests, Accessed at http://www.nepalnews.com /main /index.php/-featurearchive/1016-west-seti-hydel-marred-by-contro versy-and-conflict-of-interests.html

Annan, K (2010). Human rights dimension of poverty. Accessed at http://www2.ohchr.org/ english/issues /poverty/index.htm

Asian Development Bank (2002). Poverty Reduction in Nepal: Issues, Findings, and Approaches, ADB South Asia Department: Manila, Philippines

Basnet, G. ( 2012). Human Rights, Poverty \& Nepal. Accessed on 12 June 2013 athttp://www.nepalnews.com/home/index.php/guestcolumn/17583-human-rights-poverty-a-nepal.html

Blaikie, P.M., John, C \& Seddon, D. (1980). Nepal in crisis: growth and stagnation at the periphery, Oxford: Clarendon. 
Chhetry, D ( 2002) Understanding Rural Poverty in Nepal, Defining an Agenda for Poverty Reduction, Proceedings of the First Asia and Pacific Forum on Poverty (Volume 1), can be accessed http://www.adb.org/sites/default/files/pub/2002/Defining_Agenda _Poverty_Reduction_voll.pdf

Bourguignon, F. and Chakravarty, S. (2003), The measurement of multidimensional poverty, Journal of Economic Inequality, 1, $25-49$

Dhakal, B; Bigsby, H and Ross, C (2006) Poverty Alleviation or Aggravation? The Impacts of Community Forestry Policies in Nepal, paper prepared for presentation at the International Association of Agricultural Economists Conference, Gold Coast, Australia, August 12-18, 2006

Thanju, J.P (2008). West Seti Hydro-electric Project, Hydro Nepal: Journal of Water, Energy and Environment, vol 3: Nepal.

IMF (2003). Nepal: Poverty Reduction Strategy Paper, IMF Country Report No. 03/305: Washington, D.C.

BalKumar, K.C (2003). Migration, poverty and development in Nepal, commissioned paper for Economic and Social Commission for Asia and Pacific , Ad Hoc Expert Group Meeting on Migration and Development. 27-29 August 2003. Bangkok.

Nikku, B.R. (2009). Transboundary Water Diplomacy and Governance: Insights from Mahakali Treaty, selected for the Fourth Annual International Conference on Public Policy and Management, August 9-12 2009: India.
Regmi, A.(2004) . Democratising Micro-hydel: Structures, Systems and Agents in Adaptive Technology in the Hills of Nepal, Wageningen University Water Resource Series: Orient Longman

Sharma, S \& Gautam, B.R (2004). PRSP and Roles of Community Based Monitoring Systems (CBMS) :Case of Nepal, Poverty and Economic Policy Working Paper 2004-04, IDRC.

Sen, A (1999). Development \& Freedom, Oxford University Press

Seddon, D. (1987). Nepal, a state of poverty. New Delhi: Vikas Publictions House

Shrestha, R.S (2009). Arun-III Project: Nepal's Electricity Crisis and its Role in Current Load Shedding and Potential Role 10 Years Hence, Hydro Nepal, Isuue No 4 : Nepal

The World Bank (2003). World Development Report 2003, New York: Oxford University Press.

UNDP(1999).Report of the Satellite Symposium on "Socio-economic Causes and Consequences of HIV/AIDS: A Focus on South Asia", 25 October 1999, Accessed http://aidsouthasia.undp.org.in/publicatn/symposium/ Symp_detail.htm .

UNDP (2004). Nepal Human Development Report (HDI) 2004: A Report by United Nations Development Program

Wagle, U. (2005). Multidimensional Poverty Measurement with Economic Well-Being, Capability and Social Inclusion: A Case from Kathmandu, Nepal. Journal of Human Development, 6 (3):301-328. 